\title{
Lorlatinib Regimen
}

National Cancer Institute

\section{Source}

National Cancer Institute. Lorlatinib Regimen. NCI Thesaurus. Code C160082.

A chemotherapy regimen consisting of lorlatinib that may be used in the treatment of ALK-positive or ROS1-positive advanced non-small cell lung cancer (NSCLC). 